\title{
PARA UMA GRAMÁTICA DA LÍNGUA HÃTXA KUĨ
}

Autor: Joaquim Paulo de Lima Kaxinawá

Ano de defesa: 2014

Orientadora: Ana Suelly Arruda Câmara Cabral

Instituição: Universidade de Brasília

A tese trata de aspectos fundamentais da língua Hãtxa kuin, à luz de uma abordagem linguística antropológica. Traz uma descrição das classes de palavras da língua, pondo em foco a classe dos nomes, cujos morfemas constituintes são minuciosamente descritos. São abordados vários tipos de nomes e são colocadas em relevo as suas respectivas características específicas. Descreve pronomes, demonstrativos, quantificadores, posposiçóes, adjetivos, verbos, advérbios, conjunçôes, ideofones e interjeiçôes. Nesse viés, discute o sistema de alinhamento, propondo uma análise diferenciada, com base em novos dados do Kaxinawá falado no Brasil. Póe em relevo a interface entre tempo, aspecto, modo e modalidade, a partir de exemplos especialmente extraídos de discursos. Discute, também, aspectos culturais do povo Huni kuin, ressaltando a sua educação tradicional, contextualizando-a, mostrando como ela é responsável pela continuidade do povo Hui kuin e como tem sido a principal referência para o modelo de ensino das escolas das aldeias. O método analítico utilizado na descrição gramatical foi basicamente o que lança mão do bom conhecimento de uma língua, do contraste, da distribuição complementar, da necessidade de interpretar adequadamente as funçôes linguísticas no discurso. Nenhuma teoria em particular foi norteadora do trabalho, mas abordagens sobre temas específicos de autores diversos que contribuem para o que pode ser uma descrição de uma língua em uso, modelada na experiência cultural dos seus falantes. É a primeira tese no Brasil de autoria de um indígena sobre a sua língua nativa, a primeira apresentada em duas versôes, em Português e na língua Kaxinawá. É, portanto, a primeira tese bilíngue em Português e em uma língua indígena brasileira. 